\title{
THE DEGRADATION OF BOD AND COD OF BATIK INDUSTRY WASTEWATER USING EGERIA DENSA AND SALVINIA MOLESTA
}

\author{
Bieby Voijant Tangahu and Adistie Prestiani Putri \\ Jurusan Teknik Lingkungan, Fakultas Teknik Sipil dan Perencanaan, Institut Teknologi Sepuluh Nopember (ITS) \\ Jl. Raya ITS, Surabaya 60111 Indonesia \\ e-mail: voijant@its.ac.id; bieby2003@yahoo.com
}

\begin{abstract}
Batik industry wastewater is derived from the coloring and wax removal (pelorodan) processes. The treatment for batik wastewater can be made simple and cheap using phytotechnology principle. One of phytotechnology principles is by treating the wastewater using plants as phytotreatment agents which will absorb the pollutants in wastewater. The plants used in this study were Egeria densa and Salvinia molesta and the study used a laboratory-scale reactor in batch systems. The first performed step was acclimatization and then continued by Range Finding Test (RFT). The RFT result would give the value of pollutant's concentration to be used in the next step of the study, phytoremediation test. Phytoremediation test was conducted for 17 days. The studied parameters were Biochemical Oxygen Demand (BOD) and Chemical Oxygen Demand (COD). The result showed that the single reactor of Egeria densa reached the highest efficiency to reduce BOD and COD from thecoloring wastewater, with the efficiency of $93 \%$ for BOD and $95 \%$ for COD or equal to $94.4 \mathrm{mg}$ BOD/L and 392.2 $m g C O D / L$. For wax removal wastewater, the lowest concentrations of BOD and COD were reached in reactor with single species of Salvinia molesta within 17 days which were $99 \%$ or equivalent to $1693.1 \mathrm{mg} \mathrm{BOD/L}$ and $4338.5 \mathrm{mg} \mathrm{COD} / \mathrm{L}$.
\end{abstract}

Keywords: Batik wastewater, Egeria densa, Phytotreatment, Salvinia molesta

\section{INTRODUCTION}

The wastewater from batik industry is resulted from waxing (pemalaman), coloring, and wax removal (pelorodan) processes. The wastewater is mostly generated from the coloring as well as color and wax removal processes (Astirin \& Winarno, 2000). Textile wastewater generally has a ratio of BOD /COD around 0.25 which means that the wastewater contains a large amount of non biodegradable organic material (Al-Kdasi et al., 2004). If this wastewater is discharged directly to the environment, there will be the contamination of water which will be easily recognized by the symptom of the death of aquatic organisms. The effort to improve the quality of water contaminated by batik industry wastewater was continuesly studied. There are some processes that can be used, one of which is called phytoremediation. Phytoremediation is defined as the leaching of pollutants using plants media including trees, grasses, and aquatic plants. The processes occur could be the destruction, inactivation or immobilization of pollutants to a harmless form (Chaney et al., 1995). Phytoremediation process uses plants for the absorption, extraction, conversion and release of contaminants from one medium to another. The condition of Indonesia's tropical climate will be an advantage. Thus, it will be possible to optimize the phytoremediation technology by leveraging pollutant recovery plants (Trihadiningrum et al., 2007). 
One of the potential biological agents for bioremediator is the aquatic plant. Some aquatic plants such as Salvinia molesta and Egeria densa can be used as phytoremediation agents to absorb toxic substances in batik industry wastewater. In this research, the ability of each plant and the combination of both plants to reduce BOD and COD contents under some influencing parameters will be observed. The aim of this study is determining the concentration removal of BOD and COD of wastewater batik industry using Egeria densa and Salvinia molesta.

\section{RESEARCH METHODS}

\subsection{ACCLIMATIZATION}

The purpose of this phase is to provide seeds of plants needed for the research. This step is also for testing the plant's adaptation to the environmental condition. The reactors used to grow the plants and the reactors used in phytoremediation test were prepared using tap water. Acclimatization process was conducted by putting plants in the reactor core for 7 days in a media that is free from pollutants. This step was performed to adapt the plants to the similar conditions with the research to be conducted. At this stage, the plants must be able to adapt to the planned conditions. The characteristic of plants that are able to adapt are flourish, not dead, not wilted, and germinate. Once the plants are ready to use, they are used for the RFT (Range Finding Test) stage and the primary research.

\subsection{RANGE FINDING TEST (RFT)}

This phase aims to determine the ability of the plants to absorb pollutants at certain concentrations. Its purpose is to find the concentration range of contaminants that can be handled by the plant. Some steps that are conducted in RTF are:

- Preparation of batik wastewater with the concentration of $0 \%, 5 \%, 10 \%, 20 \%, 40 \%, 80 \%$.

- Preparation of the the plants from the acclimatization reactor to the phytoremediation reactor.

- Growing the plants in a test reactor with a certain concentrations of wastes.

- Observing the plant growth parameters after 96 hours of exposure.

\subsection{MAIN RESEARCH}

In the phytoremediation test, the batik wastewater with a specific concentration (obtained from the RTF test) was prepared. The phytoremediation tests were carried out using the same reactor as the acclimatization process. This study was repeated twice (Duplo) and was not carried out simultaneously. The study used various plant species and various types of wastewater. The previously prepared wastewater then was added to each reactor. The observations were conducted every 3 days up to day 14 
and continued at days 21 and 28. The main studied parameters, BOD and COD, were then fitted with the additional parameters such as plant morphology, fresh and dry weight of the plants, temperature, and $\mathrm{pH}$.

\section{RESULTS AND DISCUSSION}

Batik wastewater used in this research was taken from the Batik Industry in Jetis, Sidoarjo, with the characteristics as given in Table 1.

Tabel 1. Batik Industry Wastewater Characteristic

\begin{tabular}{ccccc}
\hline \multirow{2}{*}{ Parameter } & Unit & $\begin{array}{c}\text { Coloring } \\
\text { Wastewater }\end{array}$ & $\begin{array}{c}\text { Wax removal } \\
\text { (pelorodan) } \\
\text { Wastewater }\end{array}$ & $\begin{array}{c}\text { Quality Standard } \\
\text { (Kep. Gubernur Jawa } \\
\text { Timur no. 72/2013) }\end{array}$ \\
\hline BOD & $\mathrm{mg} / \mathrm{L}$ & 261.25 & 8126 & 50 \\
$\mathrm{COD}$ & $\mathrm{mg} / \mathrm{L}$ & 1066 & 10158 & 150 \\
TSS & $\mathrm{mg} / \mathrm{L}$ & 5120 & 9408 & 50 \\
Total & $\mathrm{ppm}$ & 12.32 & 14.52 & 1 \\
Chromium & - & 8.77 & 0.89 & $6-9$ \\
pH & 64 & 4348 & 40 \\
Oil and Fat & $\mathrm{mg} / \mathrm{L}$ & 64.81 & 22.8 & 8 \\
$\mathrm{NH}_{3}-\mathrm{N}$ & $\mathrm{mg} / \mathrm{L}$ & 91.8 & & \\
\hline
\end{tabular}

The concentration used for the phytoremediation test was obtained from the Range Finding Test. Concentration that could be accepted by the plant is $40 \%$ which is equivalent to the BOD concentration of $104.5 \mathrm{mg} / \mathrm{L}$ and COD of $426.4 \mathrm{mg} / \mathrm{L}$ for coloring wastewater and $20 \%$ which is equivalent to the BOD concentration of $1625 \mathrm{mg} / \mathrm{L}$ and COD of $4199 \mathrm{mg} / \mathrm{L}$ for wax removal wastewater.

\subsection{COD MEASUREMENT}

Chemical Oxygen Demand (COD) is the amount of oxygen required to oxidize the organic substances in wastewater through chemical reactions. The chemical reaction will convert the organic substances into $\mathrm{CO}_{2}$ and $\mathrm{H}_{2} \mathrm{O}$. The samples for COD test were taken from 3 diagonal points: at the top left, middle, and bottom right. The samples from each point then were mixed and homogenized. The sampling was conducted for 4 days (day 4, 8, 12,17). The method used for the analysis of COD is the titration using a closed reflux-system.

The COD analysis was carried out only for the samples in reactors containing the contaminants. The COD analysis was not conducted for the the controlling reactor plant and for the tap water media because this analysis aimed to determine the COD concentration of the waste that can be absorbed by the plants and the system without the presence of plants. Based on the analysis of COD, it is found that the effeciency of the reactor to reduce COD is as given in Figure 1 and Figure 2, while the efficiency of the 
vegetation to remove the waste is as given in Figure 3 and Figure 4. The testing should have ended at day 28, however, based on the test results, the COD parameter has decreased and met the quality standards before day 28 . Therefore, the analysis can be stopped since the efficiency had reached $99 \%$.

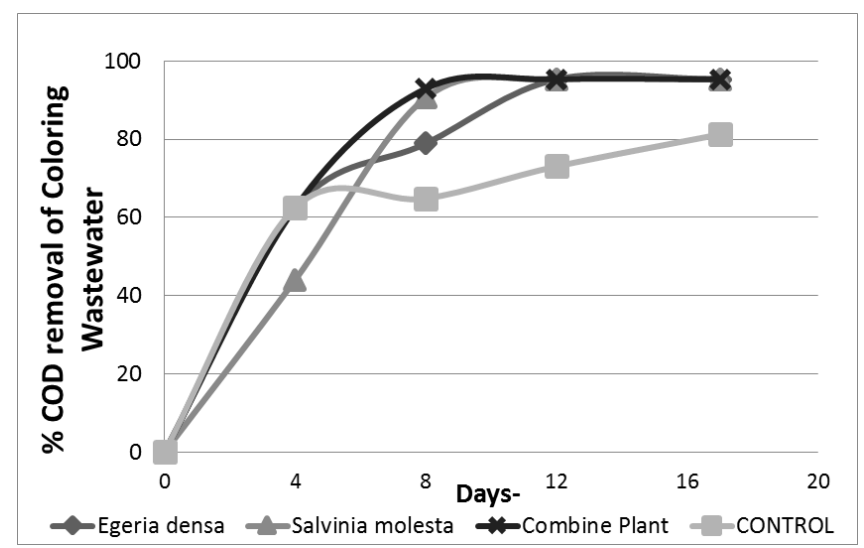

Figure 1. Removal of COD in Coloring Wastewater

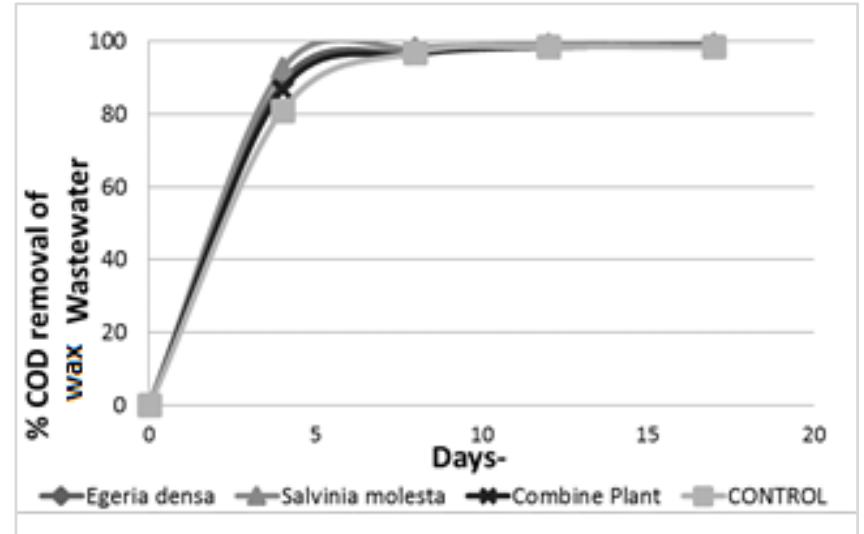

Figure 2. Removal of COD in Wax Removal Wastewater

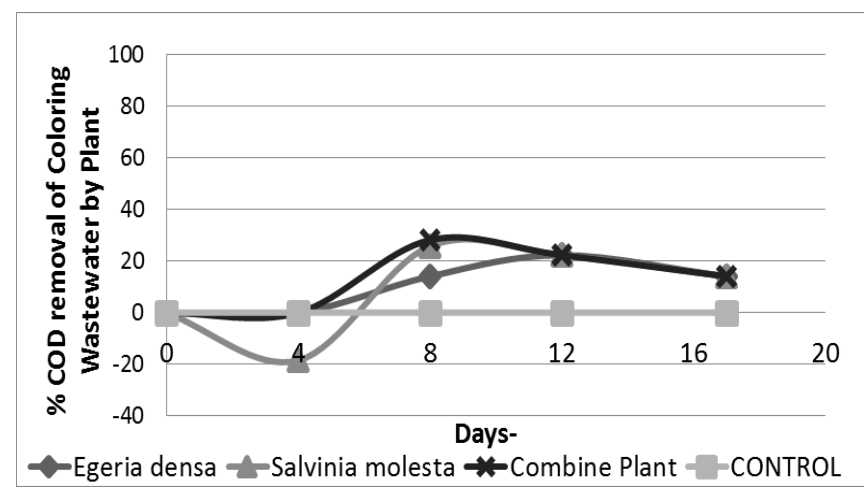

Figure 3. Removal of COD in Coloring Wastewater by Plant 


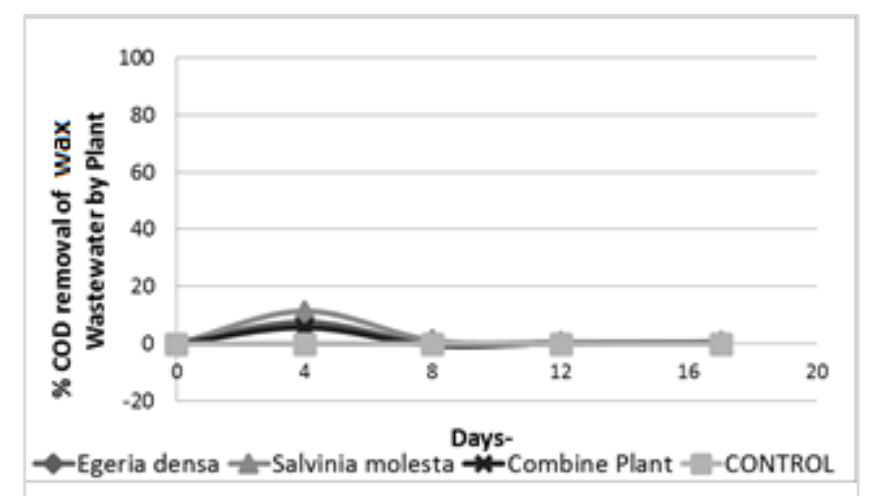

Figure 4. Removal of COD in Pelorodan Wastewater by Plant

Based on the results of the research, it was found that there was a reduction of COD in each reactor. In the early observations conducted on the day 4, it is seen that the percentage of COD removal at each reactor increases significantly. The efficiency of COD removal in the coloring wastewater reactor is $61 \%$ while with the presence of Salvinia molesta the COD removal is only $42 \%$. On the fourth day Salvinia molesta is not effective compared to the control, as shown in Figure 4. The increase of the concentration of COD is because at the initial exposure to sewage, plants experience stress conditions. In the staining waste, the ratio of $\mathrm{BOD} / \mathrm{COD}$ value is 0.2 which indicates that the waste is toxic. Plants will generate exudate which will increase the biodegradable waste in the water so that the initially toxic waste will be transformed into biodegradable waste. Basically every plant generates the exudate, but for the Salvinia molesta, the generated exudate is higher so that the BOD level of the wastewater increases. The exudate contains organic acids, phenols, enzymes and proteins (Mangkoediharjo \& Samudro, 2010).

The decline of the COD value was because the solid material had started to settle and had been oxidized. On the $4^{\text {th }}$ day, the role of the plants to remove the COD value was still not clearly visible because the waxing removal (pelorodan) waste itself was able to perform a self-recovery with its deposition. On the coloring waste, the role of the plants to reduce the COD was observeable because the supply of dissolved oxygen is quite a lot especially from the photosynthesis of the plants that causes the decomposition of the organic material to be more effective.

\subsection{BOD MEASUREMENT}

The BOD test aimed to calculate the oxygen required by the microorganisms to degrade the organic substances in wastewater. This test is one of the most important tests in monitoring the activity of river pollution. By measuring the BOD level, it is possible to determine the level of environmental contamination at any time (Wardhana, 1995). BOD value is also used to measure the abundance of 
organic waste as an effort to plan and evaluate the efficiency of the biological treatment system of organic waste management. Changes in organic matter content expressed by the BOD value will occur in every cleaning process of the rivers polluted by organic wastes (Hammer, 1997). The BOD test was conducted for 5 days. The sampling was carried out together with the sampling for COD analysis. Three sampling points were mixed and homogenized, conducted every 4 days. The BOD removal efficiency can be seen in Figure 5 and Figure 6.

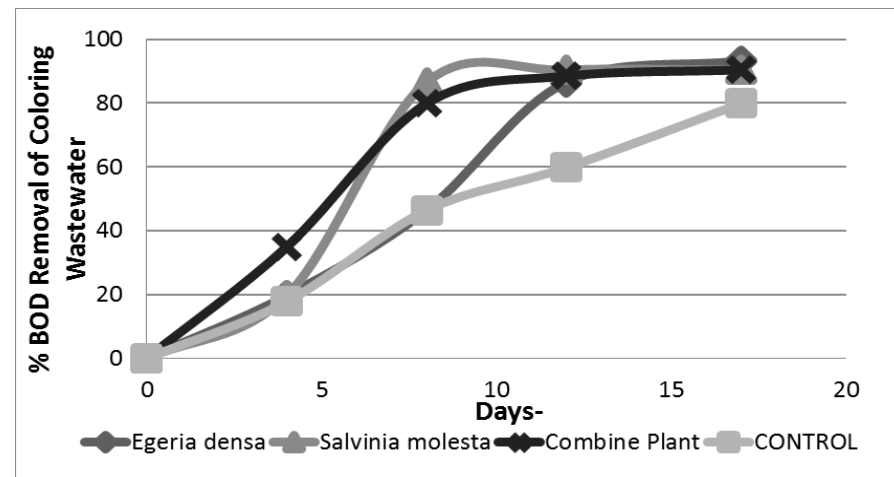

Figure 5. Removal of BOD in Coloring Wastewater

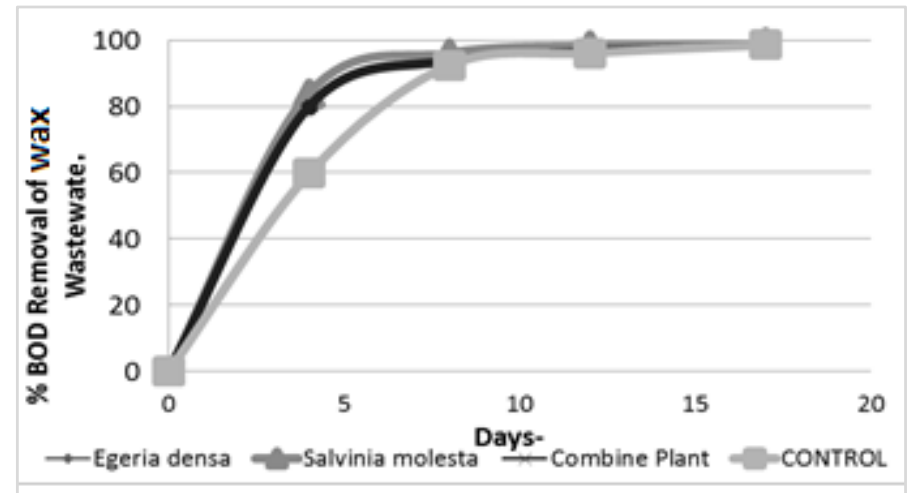

Figure 6. Removal of BOD in Wax Removal (Pelorodan) Wastewater

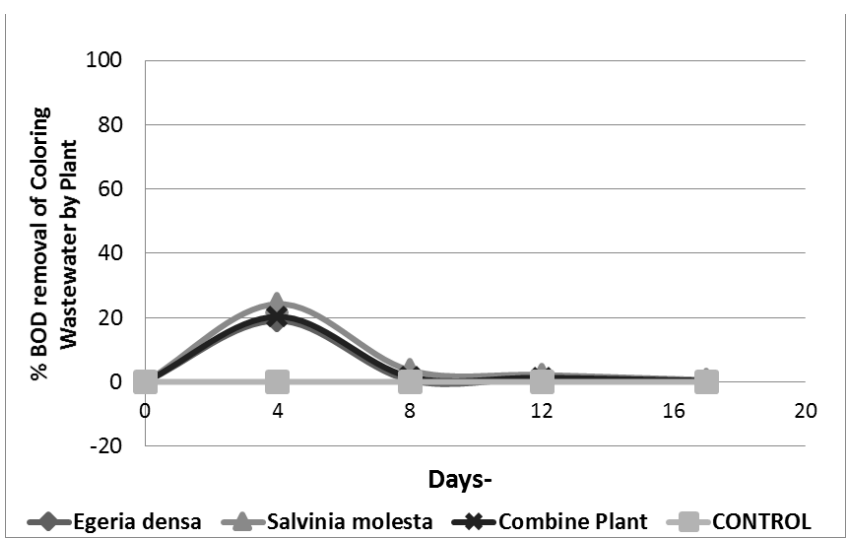


Figure 7. Removal of BOD in Coloring Wastewater by Plant

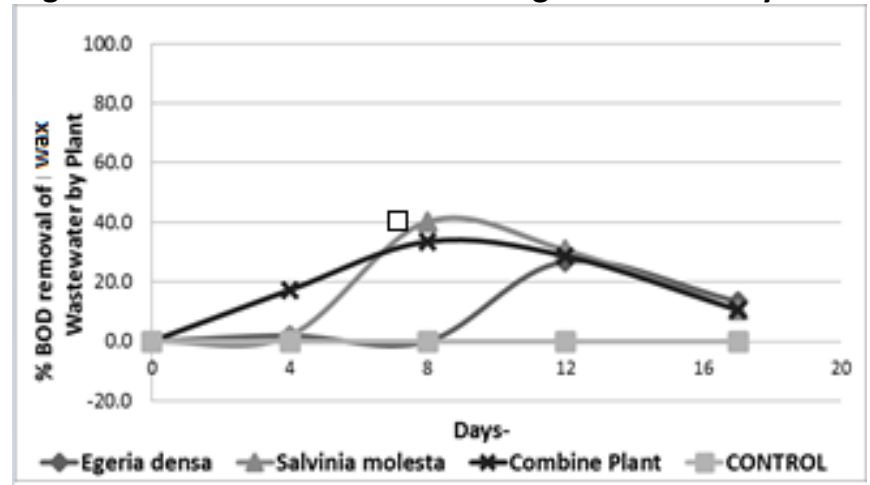

Figure 5. Removal of BOD in Wax Removal (Pelorodan) Wastewater by Plant

Based on the results, it was found that there is a reduction of BOD value in each reactor. In the early observations conducted on day 4 , it is seen that the percentage of BOD removal at each reactor increases significantly. The coloring waste reactor has an average efficiency of $21 \%$ for a single plant, $37 \%$ for the combination of both plants, and $19 \%$ for the controlling reactor.

The percentage of BOD removal in each reactor increases until the end of the observation, day 17. The reactor containing the colorinf waste has the BOD removal efficiency of 99\% for a single reactor Egeria densa, $96 \%$ for Salvinia molesta and the combination of both plants while the controlling reactor for the coloring wastewater has an efficiency of $85 \%$.

On day 4, the efficiency of BOD removal in the reactor containing the wax removal wastewater is $79 \%$ for Egeria densa, $84 \%$ for Salvinia molesta and $80 \%$ for the combination of both plants. The BOD removal efficiency in the controlling reactor for wax removal is only $60 \%$. On day 17 , the BOD removal efficiency for each reactor reaches $99 \%$. The high efficiency of BOD removal in the wax removal (pelorodan) wastewater is due to the characteristics of the waste which settles easily. The $\mathrm{BOD}_{5}$ process of elimination occurs via physical and biological processes (Crites \& Tchobanoglous, 1998). Physical process includes the deposition and capturing of the particulate material in a vacuum on the media. Microorganisms play a pivotal role in the removal of organic material, thus, the process requires oxygen. The oxygen flows to the roots through the trunk after it diffuses from the atmosphere through the leaf pores (Vymazal, 2008).

\subsection{RATIO OF BOD / COD}

The ratio analysis of BOD/COD was conducted to determine the level of biodegradability of organic substances in wastewater. The wastewater is said to be stable if the ratio of BOD/COD is less than 0.1. 
If the ration of BOD/COD is more than 0.1, the wastewater is said to be biodegradable (Mangkoedihardjo \& Samudro, 2010). COD is the amount of oxygen required to chemically oxidize organic materials in the water. If the unprocessed organic material is discharged into the water body, the bacteria will use the oxygen for the degradation process of the organic material. The COD value is usually higher than the BOD value. The graph of BOD/COD ration in this work can be seen in Figure 9 and Figure 10.

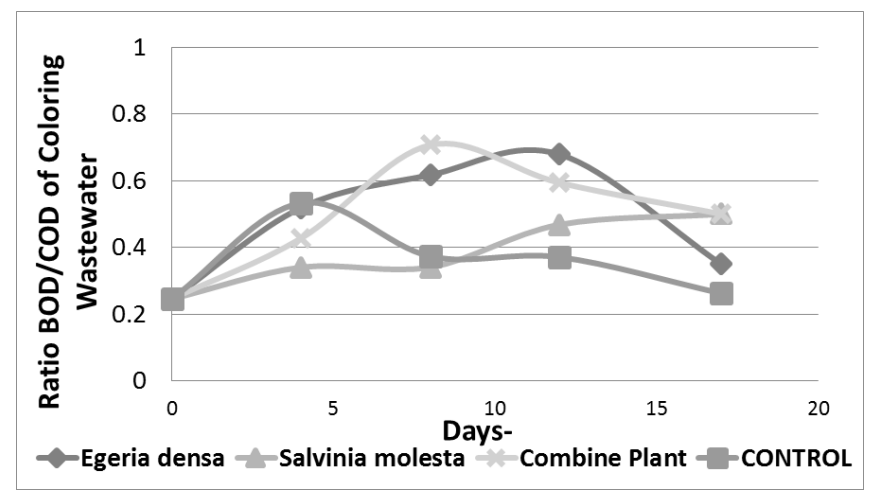

Figure 9. BOD/COD Ratio of Coloring Wastewater

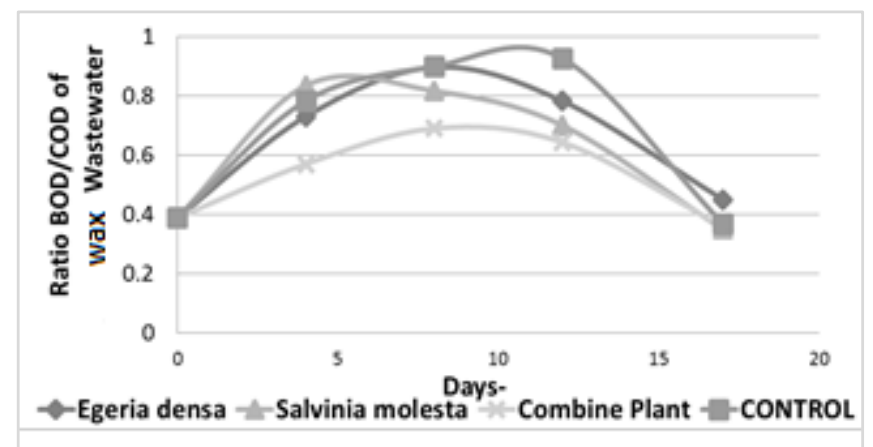

Figure 10. BOD/COD Ratio of Wax Removal (Pelorodan) Wastewater

Based on the calculation, the ratio of BOD/COD tends to increase and decrease later. The increase of the $\mathrm{BOD} / \mathrm{COD}$ ratio might be due to the increase of BOD value which is caused by the increase of the microorganisms' activity in the wastewater. Biodegradation is defined as a degradation process of organic compounds by microorganisms in soil, water, or the wastewater treatment plant (Kastono \& Siswandono, 2005). The rate of contaminants removal after sewage treatment process can be seen from the parameter value of wastewater in the bioreactor. Reduction of the organic substances in the wastewater as a result of the biodegradation process will reduce the BOD value, because the dissolved oxygen in the water is absorbed by microorganisms to breakdown or degrade the organic waste (Malec et al., 2009). The degradation process will produce volatile materials. The presence of volatile materials is characterized by the stinky smell. In addition, the organic waste material can also react with oxygen 
dissolved in the water through the usual oxidation reaction. The more the organic waste material in water, the less the residual dissolved oxygen in water will be. By looking at the amount of dissolved oxygen in the water, the level of environmental contamination can be determined (Wardhana, 1995).

\section{CONCLUSION}

Based on this research it can be concluded that:

The concentration of the waste can be tolerated by Egeria densa and Salvinia molesta are:

- The highest efficiency to reduce the BOD and COD in the coloring wastewater is the reactor containing Egeria densa with the efficiency of $93 \%$ for BOD and 95\% for COD. These values are equivalent to $94.4 \mathrm{mg} / \mathrm{l} \mathrm{BOD}$ and 392.2, $\mathrm{mg} / 1 \mathrm{COD}$ within 17 days.

- The highest efficiency to reduce the BOD and COD in the wax removal (pelorodan) wastewater is the reactor containing Salvinia molesta with the efficiency of 99\% for BOD and COD. These values are equivalent to $1693.1 \mathrm{mg} / \mathrm{l}$ BOD and $4338.5 \mathrm{mg} / \mathrm{l} \mathrm{COD}$ within 17 days.

\section{REFERENCE}

Al-Kdasi, A., Idris, A., Saed, K. dan Guan, C.T. 2004. "Treatment of textile wastewater byadvancedoxidation processes”. Global Nest the Int. J. 6: 222-230.

Astirin, Okid Parama dan Winarno, Kusumo. 2000. "Peran Pseudomonas dan Khamir dalam Perbaikan Kualitas dan Dekolorisasi Limbah Cair Industri Batik Tradisional”. Surakarta : Universitas Negeri Semarang, B i o S M A R T , 2, 1, 13 - 19

Chaney R L, Brown S, Li Y-M, Angle J S, Homer F and Green C 1995 Potential use of metal hyperaccumulators. Mining Environ. Manage. 3(3), 9-11

Crites, R, and Tchobanoglous. 1998. Small and Decentralized Wastewater Management System.New York: McGraw-Hill.

Hammer, M. J. 1997. Water and Wasterwater Tecnology. John Willey and Sons, New York

Kastono, D. H. Sawitri, dan Siswandono. 2005. "Pengaruh Nomor Ruas Setek dan Dosis Pupuk Urea Terhadap Pertumbuhan dan Hasil Kumis Kucing”. Jurnal Ilmu Pertanian. 12(1): 56-64. 
Malec, P., Maleva, M. G., Prasad, M. N. V., Strzalka, K. 2009. Identification and Characterization of Cd-induced Cd Detoxification : Aquat. Toxicol. 95, 213-221

Mangkoedihardjo, S. dan Samudro,G. 2010. Fitoteknologi Terapan. Graha Ilmu, Yogyakarta.

Trihadiningrum, Y. Basri, H, Mukhlisin, M.2007. Phytotechnology, a Nature-Based Approach for Sustainable Water Sanitation and Conservation ITS : Surabaya

Vymazal, J. 2008. Waterwaste Treatment in Constructed Wetlands with Horizontal Sub-Surface Flow. Czech Republic : Springer.

Wardhana, Wisnu Arya, 1995, Dampak Pencemaran Lingkungan, Penerbit Andi Offset Yogyakarta. 